\section{Commentary: Three-dimensional printing in congenital cardiac surgery: The future is now}

\author{
Harold M. Burkhart, MD, ${ }^{\mathrm{a}}$ and Arshid Mir, $\mathrm{MD}^{\mathrm{b}}$
}

The American Board of Thoracic Surgery and the Thoracic Surgery Directors Association understand the importance of incorporating simulation into the training of resident physicians in thoracic surgery. ${ }^{1,2}$ Many publications report the benefits of simulation-based training in cardiothoracic surgery residency. ${ }^{3-5}$ The opportunities for simulation to be integrated into training keep expanding. Congenital heart disease is often associated with complex and unique spatial relationships that can be difficult to grasp from standard 2-dimensional imaging with echocardiography, computed tomography, or magnetic resonance imaging. Most of the time this would involve 3-dimensional (3D) mental reconstruction of 2-dimensional images. Indeed, the need for this visualization is supported by the fact that all 3 modalities-echocardiography, computed tomography, and magnetic resonance imaging - have evolved to provide 3D imaging. Utilizing 3D printed models for congenital cardiac surgical education represents the holy grail in training residents to perform complex cardiac operations without putting patient lives at risk.

Van Arsdell and colleagues ${ }^{6}$ provide their expert opinion on using 3D printing in congenital cardiac surgery. This group has been at the forefront of the push to utilize pliable $3 \mathrm{D}$ printed models in the surgical training of congenital cardiac surgery fellows. Three years ago they reported their experience with 81 surgeons or trainees performing procedures such as the arterial switch or Norwood on 3D printed models. The participants agreed that the simulation training was helpful and would

\footnotetext{
From the ${ }^{\mathrm{a} D i v i s i o n}$ of Cardiovascular and Thoracic Surgery and ${ }^{\mathrm{b}}$ Section of Pediatric Cardiology, University of Oklahoma Health Sciences Center, Oklahoma City, Okla.

Disclosure: Authors have nothing to disclose with regard to commercial support.

Received for publication Jan 30, 2020; accepted for publication Feb 1, 2020; available ahead of print Feb 14, 2020.

Address for reprints: Harold M. Burkhart, MD, Division of Cardiovascular and Thoracic Surgery, University of Oklahoma Health Sciences Center, PO Box 26901, WP-2230, Oklahoma City, OK 73105 (E-mail: Harold-burkhart@ouhsc. edu).

J Thorac Cardiovasc Surg 2020;160:520-1

$0022-5223 / \$ 36.00$

Copyright (c) 2020 by The American Association for Thoracic Surgery

https://doi.org/10.1016/j.jtcvs.2020.02.018
}

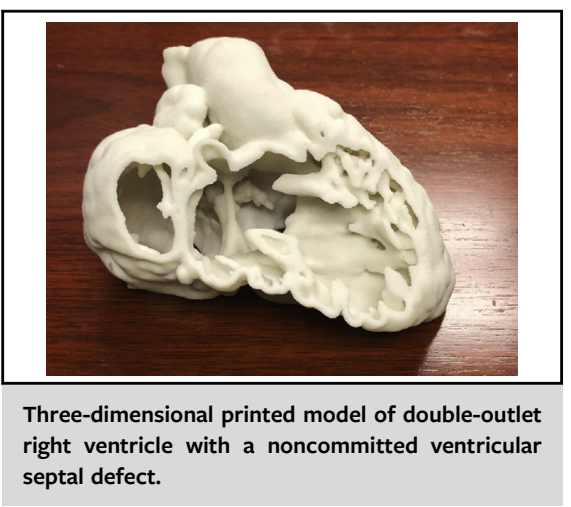

CENTRAL MESSAGE

Three-dimensional printing is

rapidly evolving and the time to

incorporate it into congenital

cardiac surgical training has

arrived.

consider integrating this into their programs. ${ }^{7}$ Van Arsdell and colleagues ${ }^{6}$ point out that their congenital cardiac models have been developed and used for training purposes around the world.

There are several points that bear reiterating. First, the models are evolving quickly, going from firm opaque material to pliable clear material. They are also more user friendly from a surgical standpoint. Newer models incorporate atrioventricular valves, an area that in the past has been a detractor for some. Despite the limitations of the models, trainees have all found value in this simulation exercise. Having residents rehearse operations by setting up the procedure, shaping patches, figuring out sewing angles and hand positions, and sorting out the conduct of the operation has to have some worth. This preparedness will undoubtedly be reflected at the time of real-life operations making one question why this has not been made a requirement in all programs. The stakes are too high, results are being scrutinized publicly, and junior surgeons' careers are at risk-the days of learning on a patient are obsolete. Lastly, this technology is moving rapidly and will play a role in bioprinting with personalized cardiac structure construction. ${ }^{8}$ Limitations such as cost and time for image segmentation and model production will not be limitations for long. 
It appears that we have at our disposal what we have wanted: The ability to print a 3D model of a congenital cardiac patient's heart. This not only allows for improved patient and physician education, but enables heart teams to review a corrective plan and practice it preoperatively. The future of simulation in congenital cardiac surgery is now. We owe it to our patients to embrace it.

\section{References}

1. Hicks GL Jr, Brown JW, Calhoon JH, Merrill WH. You never know unless you try. J Thorac Cardiovasc Surg. 2008;136:814-5.

2. Feins RH, Burkhart HM, Conte JV, Coore DN, Fann JI, Hicks GL Jr, et al. Simulation-based training in cardiac surgery. Ann Thorac Surg. 2017;103: 312-21
3. Hicks GL Jr, Gangemi J, Angona RE Jr, Ramphal PS, Feins RH, Fann JI. Cardiopulmonary bypass simulation at the Boot Camp. J Thorac Cardiovasc Surg. 2011; 141:284-92.

4. Burkhart HM, Riley JB, Hendrickson SE, Glenn GF, Lynch JJ, Arnold JJ, et al. The successful application of simulation-based training in thoracic surgery residency. J Thorac Cardiovasc Surg. 2010;139:707-12.

5. Fann JI, Calhoon JH, Carpenter AJ, Merrill WH, Brown JW, Poston RS, et al Simulation in coronary artery anastomosis early in cardiothoracic surgical residency training: the Boot Camp experience. J Thorac Cardiovasc Surg. 2010; 139:1275-81

6. Van Arsdell GS, Hussein N, Yoo SJ. Three-dimensional printing in congenital cardiac surgery: now and the future. J Thorac Cardiovasc Surg. 2020;160:515-9.

7. Yoo SJ, Spray T, Austin EH, Yun TJ, Van Arsdell GS. Hands-on surgical training of congenital heart surgery using 3-dimensional print models. J Thorac Cardiovasc Surg. 2020;153:1530-40.

8. Best C, Strouse R, Hor K, Pepper V, Tipton A, Kelly J, et al. Toward a patient-specific tissue engineered vascular graft. J Tissue Eng. 2018;9:2041731418764709. 